\title{
Mathematical model for frequency modulation in the respiratory network
}

\author{
Natalia Toporikova ${ }^{1,2^{*}}$, Robert Butera ${ }^{1,2}$ \\ From Twentieth Annual Computational Neuroscience Meeting: CNS*2011 \\ Stockholm, Sweden. 23-28 July 2011
}

Neuromodulators, such as amines and neuropeptides, alter the activity of neurons and neuronal networks. In this work, we investigate how neuromodulators which activate G-proteins and second messenger systems can modulate the frequency of bursting neurons in a critical portion of the respiratory neural network, the pre-Bötzinger complex $(\mathrm{pBC})$. Inspiratory neurons in the $\mathrm{pBC}$ produce a regular bursting rhythm in phase with the activity of inspiratory muscles in the diaphragm. These neurons are a vital part of the ponto-medullary neuronal
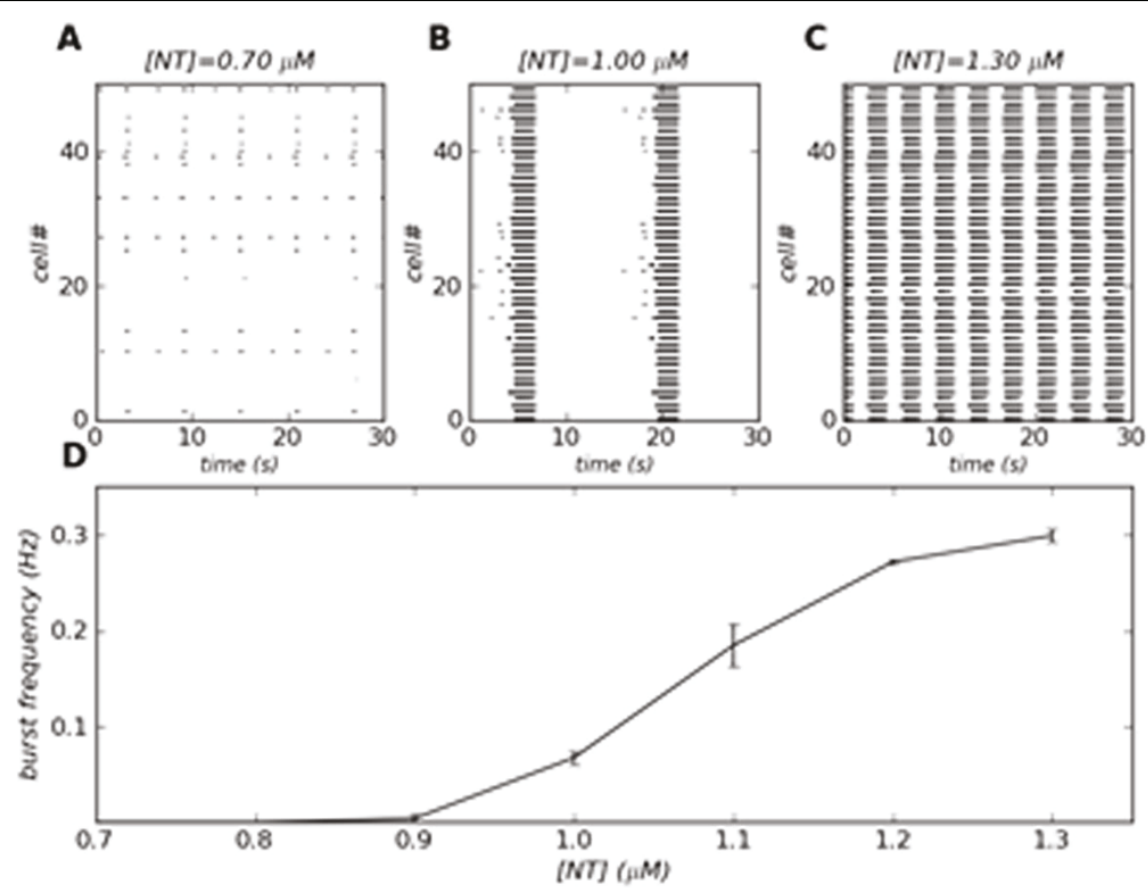

Figure 1 Inspiratory frequency modulation of pBC by excitatory neurotransmitters, which act on $G_{q}$-coupled receptor. [NT] represents neurotransmitter concentration. (A-C) Example of raster plots for three different neurotransmitter concentrations. (A) Rhythmic activity is absent for low concentration of neurotransmitter $([N T]=0.7 \mu M)$. (B) Increase in neuromodulatory tone $([N T]=1 \mu M)$ results in a slow bursting rhythm. (C) Elevation of neurotransmitter concentration $([N T]=1.3 \mu \mathrm{M})$ increases the burst frequency in $\mathrm{pBC}$. (D) Burst frequency of pBC neurons as a function of neurotransmitter concentration. The vertical bars represent the standard error from an average of 10 network simulations.

\footnotetext{
* Correspondence: ntoporikova3@gatech.edu

'Laboratory for Neuroengineering, Georgia Institute of Technology, Atlanta,

GA, 30332-0250, USA

Full list of author information is available at the end of the article
} 
network, which generates a stable respiratory rhythm [1]. The frequency of $\mathrm{pBC}$ depends on the concentration of Serotonin (5-HT) and Substance P (SP), neurotransmitters released by the nearby Raphe nucleus. Both neurotransmitters, 5-HT and SP, affect $\mathrm{pBC}$ neurons by activating receptors coupled with the $G_{q}$ protein pathway, thereby inducing $\mathrm{Ca}^{2+}$ release from the Endoplasmic Reticulum $(E R)$.

We have previously developed a mathematical model of the $\mathrm{pBC}$ neuron, which incorporates explicit activation of $G_{q}$-protein coupled receptors, and have shown that activation of these receptors can result in $\mathrm{Ca}^{2+}$ oscillations in the dendritic compartment [2]. The model exhibits two independent bursting mechanisms bursting in the soma depends on persistent sodium current, whereas bursting in the dendrite follows $\mathrm{Ca}^{2+}$ oscillations. It has been recently found that the connection between the $\mathrm{pBC}$ and the Raphe nucleus is bi-directional: not only does the Raphe nucleus release 5-HT and SP to modulate the frequency of $\mathrm{pBC}$ neurons, but also the rhythmic activity in the $\mathrm{pBC}$ increases the firing of Raphe neurons [3]. In this work, we extend our model to a network of $\mathrm{pBC}$ neurons while incorporating this newly discovered interaction between Raphe and pBC nuclei.

Using a simulated 50-cell network of excitatory connected $\mathrm{pBC}$ neurons with a heterogeneous distribution of persistent sodium conductance and ER $\mathrm{Ca}^{2+}$, we show that a tonic release of neurotransmitters acting on the $G_{q}$ protein pathway increases the number of intrinsic bursters in such a network. However, when we simulated the application of different concentrations of SP or 5 -HT, there was no dose-dependent frequency modulation. We then added a positive feedback between the Raphe excitability and $\mathrm{pBC}$ activity, representing the release of neurotransmitters from Raphe, and found that this feedback induces frequency modulation the $\mathrm{pBC}$ neurons (Figure 1). Thus, our model shows that the frequency of the respiratory rhythm can be modulated via phasic release of 5-HT and SP from the Raphe nucleus.

\section{Author details}

${ }^{1}$ Laboratory for Neuroengineering, Georgia Institute of Technology, Atlanta, GA, 30332-0250, USA. ${ }^{2}$ School of Electrical and Computer Engineering, Georgia Institute of Technology, Atlanta, GA, 30332-0250, USA.

Published: 18 July 2011

\section{References}

1. Smith JC, Ellenberger HH, Ballanyi K, Richter DW, Feldman JL: Pre-Botzinger complex: a brainstem region that may generate respiratory rhythm in mammals. Science 1991, 254:726-729.

2. Toporikova N, Butera RJ: Two types of independent bursting mechanisms in inspiratory neurons: an integrative model. J Comput Neurosci 2010, [Epub ahead of print].

3. Ptak K, Yamanishi T, Aungst J, Milescu LS, Zhang R, Richerson GB, Smith JC: Raphe neurons stimulate respiratory circuit activity by multiple mechanisms via endogenously released serotonin and substance P. J Neurosci 2009, 29:3720-3737.

doi:10.1186/1471-2202-12-S1-P25

Cite this article as: Toporikova and Butera: Mathematical model for

frequency modulation in the respiratory network. BMC Neuroscience 2011 12(Suppl 1):P25.

\section{Submit your next manuscript to BioMed Central and take full advantage of:}

- Convenient online submission

- Thorough peer review

- No space constraints or color figure charges

- Immediate publication on acceptance

- Inclusion in PubMed, CAS, Scopus and Google Scholar

- Research which is freely available for redistribution

Submit your manuscript at www.biomedcentral.com/submit
C Biomed Central 